\title{
Soil health management under vermicompost based integrated nutrient management in wheat
}

\author{
Deo Kumar, Ashok Kumar, Sanjeev Kumar Gupta, Sunil Kumar and S. K. Choudhary
}

Received : 20.02.2018; Revised : 05.05.2018; Accepted : 19.05.2018

\section{MEMBERS OF RESEARCH FORUM:}

Corresponding author : Sanjeev Kumar Gupta, Bihar Agricultural University, Sabour, Bhagalpur (Bihar) India Email: sanjeevgupta1979@ rediffmail.com
Co-authors :

Deo Kumar, Banda University of Agriculture and Technology, Banda (U.P.) India

Ashok Kumar, Sardar Vallabh Bhai Patel University of Agriculture and Technology, Meerut (U.P.) India

Sunil Kumar and S. K. Choudhary, Bihar Agricultural University, Sabour, Bhagalpur (Bihar) India

\section{Summary}

The yield of wheat ranged from 29.16 to 45.14 and 29.56 to $49.14 \mathrm{q} \mathrm{ha}^{-1}$ during $2005-06$ and 2006-07, respectively was influenced significantly by different treatments. During 2005-06 maximum grain yield $\left(45.14 \mathrm{q} \mathrm{ha}^{-1}\right)$ was recorded in case of treatment $\mathrm{T}_{10}$ ( 3 tonnes vermicompost $+100 \%$ NPK of RDF), where 100\% NPK with vermicompost @ $3.0 \mathrm{t} \mathrm{ha}^{-1}$ was applied, was found statistically at par with treatment $\mathrm{T}_{7}$ (3 tonnes vermicompost $+75 \% \mathrm{NPK}$ of RDF), where vermicompost @ $3.0 \mathrm{t} \mathrm{ha}^{-1}$ was applied with 75\% NPK and significantly higher than the rest of the treatment. Similar trend of treatments effect on grain yield was also obtained during second year i.e. 2006-07. With exception of $\mathrm{T}_{2}$ (one tonne vermicompost $+50 \%$ NPK of RDF), grain yield recorded in $\mathrm{T}_{1}$ (150: 60: 40: as NPK, recommended dose of fertilizers), where 100\% NPK was supplemented through inorganic source was found significantly lower than the rest of the treatments. Graded does of vermicompost with similar does of NPK influenced the grain yield of wheat significantly during both the years with exception of $\mathrm{T}_{8}$ (one tonnes vermicompost $+100 \% \mathrm{NPK}$ of $\mathrm{RDF}$ ) and $\mathrm{T}_{9}$ (two tonnes vermicompost $+100 \% \mathrm{NPK}$ of RDF). Results revealed that $50 \%$ NPK can be substituted by the application of @1.0 $\mathrm{t} \mathrm{ha}^{-1}$ vermicompost as the grain yield recorded in $\mathrm{T}_{1}$ (150: 60: 40: as NPK, recommended dose of fertilizers) and $\mathrm{T}_{2}$ (one tonne vermicompost $+50 \%$ NPK of RDF), was statistically similar while grain yield increased significantly due to application of vermicompost @ $2.0 \mathrm{t} \mathrm{ha}^{-1}$ with $50 \%$ NPK. Application of different does of vermicompost with 75\% NPK yielded significantly higher than the $\mathrm{T}_{1}$ (150: 60: 40: as NPK, recommended dose of fertilizers), where only $100 \%$ NPK was applied during both the years. No significantly variation in grain yield of wheat was found between the treatments having application of $1 \mathrm{t} \mathrm{ha}^{-1}$ vermicompost with either $50 \%$ or $75 \%$ NPK but yield varied significantly between treatments having the application of $1 \mathrm{t} \mathrm{ha}^{-1}$ vermicompost with $50 \%$ or $100 \%$ NPK. Similarly no variation was also found between $\mathrm{T}_{3}$ (two tonne vermicompost $+50 \% \mathrm{NPK}$ of RDF) and $\mathrm{T}_{6}$ (two tonne vermicompost $+75 \% \mathrm{NPK}$ of $\mathrm{RDF}$ ) and $\mathrm{T}_{4}$ (three tonne vermicompost $+50 \% \mathrm{NPK}$ of RDF) and $\mathrm{T}_{7}$ (three tonnes vermicompost $+75 \%$ NPK of RDF), while $\mathrm{T}_{4}$ (three tonne vermicompost $+50 \% \mathrm{NPK}$ of RDF) and $\mathrm{T}_{10}$ (three tonnes vermicompost $+100 \%$ NPK of RDF), varied significantly during both the years. This implies that application of $3.0 \mathrm{t} \mathrm{ha}^{-1}$ of vermicompost along with $75 \% \mathrm{NPK}$ is a better combination for optimum crop yield. This combination also enhanced the physical, chemical properties of soil by improving the availability of different nutrients.

Key words : Earthworms, Vermicompost, Chemical fertilizers, Soil fertility, Plant productivity

How to cite this article : Kumar, Deo, Kumar, Ashok, Gupta, Sanjeev Kumar, Kumar, Sunil and Choudhary, S. K. (2018). Soil health management under vermicompost based integrated nutrient management in wheat. Asian J. Soil Sci., 13 (1) : 40-44 : DOI : 10.15740/HAS/AJSS/13.1/40-44. Copyright@ 2018: Hind Agri-Horticultural Society. 